Quebec Cooperative Study

of Friedreich's Ataxia

\title{
Taurine and Beta-Alanine Uptake in Cultured Human Skin Fibroblasts from Patients with Friedreich's Ataxia
}

\author{
S.B. MELANCON, B. GRIGNON, M.POTIER AND L. DALLAIRE
}

SUMMARY: Taurine and $\beta$-alanine uptake kinetics were studied in cultured skin fibroblasts from 9 patients with Friedreich's Alaxia and 8 controls. No significant difference was observed. The data support the presence of normal $\beta$-amino acid carrier protein in Friedreich's Ataxia cell membrane.

RÉSUMÉ: L'incorporation de taurine et de $\beta$-alanine procède selon des paramètres de cinétique comparables dans les fibroblastes cutanés normaux et de patients souffrant d'Ataxie de Friedreich. Ces résultats militent en faveur de la normalité des protéines membranaires responsables $d u$ transport des acides $\beta$-aminés dans l'Ataxie de Friedreich.

From le Centre de Recherche Pédiatrique de l'Hôpital Ste-Justine, Département de Pédiatrie, Université de Montréal

Reprint requests for the complete supplement on Friedreich's Ataxia (Phase Two, Part Two) to:

Dr. André Barbeau, M.D., Clinical Research Institute of Montreal, 110 Pine Avenue West, Montreal, Quebec, Canada H2W IR7.

\section{INTRODUCTION}

Amino acid transport studies in cultured human skin fibroblasts have been relatively few and were generally intended to demonstrate defects comparable to those found in kidney and intestinal cells of patients with diverse metabolic errors such as; cystinuria (Groth and Rosenberg, 1972), cystinosis (Kaye and Nadler, 1976), Hartnup disease (Booth and Nadler, 1975; Groth and Rosenberg, 1972), hyperglycinemia (Revsin and Morrow, 1976), $\gamma$-glutamyl transpeptidase deficiency (Pellefigue et al., 1976), and $\alpha$-methyl-acetoacetyl-CoA $\beta$-ketothiolase deficiency (Hillman and Otto, 1974). Recent work by Ullrich and Fromter (1978) have suggested that amino acid transport in the contraluminal plasma membrane of kidney tubular epithelium differs from basal-lateral membranes and behaves more like the fibroblast transport systems. Fibroblasts then would appear suitable for investigation of amino acid conservation defects not limited to kidney and intestinal cells. Previous studies by Lemieux et al. (1976) and Butterworth et al. (1978) in Friedreich's and experimental ataxias have shown reduced levels of taurine in cerebrospinal fluid and cerebellum, respectively. These observations led us to investigate taurine transport in cultured fibroblasts from patients with Friedreich's Ataxia.

The finding of reduce uptake rates of taurine in fibroblasts could have been extended to other body systems and might provide an explanation for some of the neurologic, cardiac, hepatic, and renal defects found in Friedreich's Ataxia (Barbeau, 1978).

\section{METHOD}

Skin biopsies were obtained with informed consent from nine patients with Friedreich's Ataxia and eight control subjects. Fibroblast cultures and amino acid uptake experiments were conducted as previously described (Melançon et al., 1979) using taurine-1-14 $\mathrm{C}$ and $\beta$-alanine- $1-{ }^{14} \mathrm{C}$ (New England Nuclear).

\section{RESULTS}

Taurine and $\beta$-alanine uptake was linear with time up to 90 minutes at extracellular concentrations varying from $5 \mu \mathrm{M}$ to $0.25 \mathrm{mM}$ (fig. 1). The rate of $\beta$-amino acids uptake was also linear, with increasing concentrations of the amino acids in the incubation medium up to $0.25 \mathrm{mM}$. At higher concentrations of taurine and $\beta$ alanine, the rate of uptake decreased without saturation. The apparent $\mathrm{Km}$ and Vmax of taurine and $\beta$-alanine uptake are illustrated in table $I$. Friedreich's Ataxia fibroblasts showed lower $\mathrm{Km}$ and higher Vmax than control fibroblasts, but these differences were not statistically significant.

\section{DISCUSSION}

Our results suggest that fibroblasts from patients with Friedreich's Ataxia incorporate taurine and $\beta$-alanine at rates comparable to normal fibroblasts. The $\mathrm{Km}$ for maximum velocity of taurine uptake in fibroblasts is approximately half the mean plasma taurine concentration in man (Lemieux et al., 1976). This comparison 


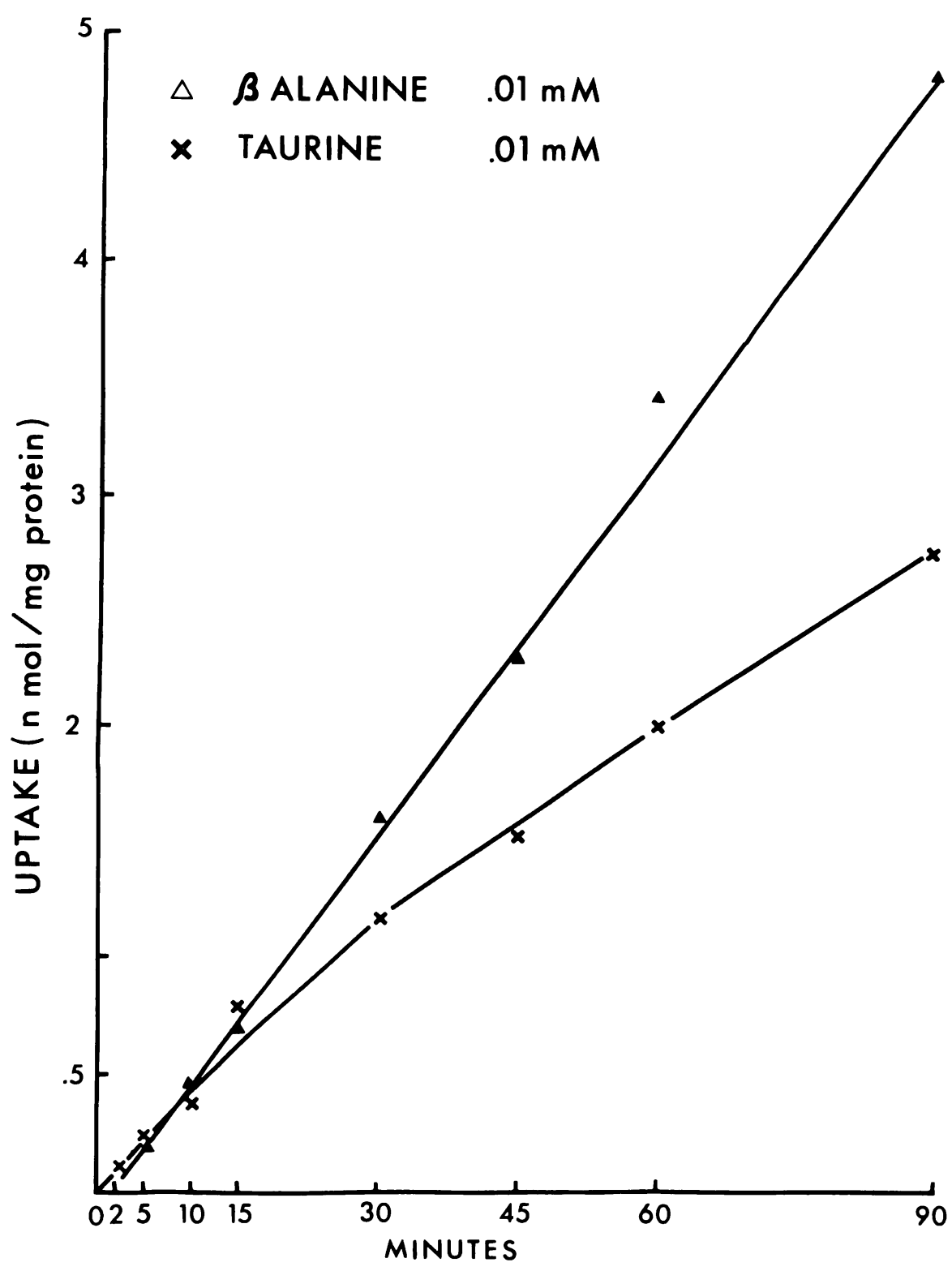

Figure 1 -Time course of $\beta$-amino acid uptake by cultured human skin fibroblasts.

TABLE I

Kinetics of taurine and $\beta$-alanine uptake by cultured skin fibroblasts at low substrate concentration $(.005-.250 \mathrm{mM})$

\begin{tabular}{|c|c|c|c|c|}
\hline & \multicolumn{2}{|c|}{ Taurine } & \multicolumn{2}{|c|}{$\beta$-Alanine } \\
\hline & $\mathbf{K} \mathbf{m} *$ & $V \max *$ & Km* & $V \max *$ \\
\hline Controls (8) & $.023 \pm .012$ & $.152 \pm .110$ & $.081 \pm .059$ & $.226 \pm .230$ \\
\hline Friedreich (9) & $.014 \pm .006$ & $.222 \pm .102$ & $.051 \pm .023$ & $.240 \pm .103$ \\
\hline
\end{tabular}

* $\mathrm{Km}$ in $\mathrm{mM}$; $V \max$ in $\mathrm{nmol} / \mathrm{min} / \mathrm{mg}$ protein; mean $\pm \mathrm{SD}$. would support the view that intracellular taurine levels are easily maintained through this high affinity low $\mathrm{Km}$ uptake system even at half reduced plasma taurine concentration. The uptake of $\beta$-alanine follows a slightly different pattern. Plasma levels of $\beta$-alanine are normally too low for accurate estimation by standard automated amino acid analyzer methods. It is thus expected that fibroblast uptake would proceed below maximum velocity in vivo.

Taurine uptake by platelets from patients with Friedreich's Ataxia was recently studied (Filla et al, 1978) and found to be normal. These results and our data with cultured fibroblasts do not support the presence of a genetic defect in $\beta$-amino acid membrane protein carriers in Friedreich's Ataxia. On the contrary, an apparently reduced $\mathrm{Km}$ and increased $\mathrm{Vmax}$ as compared to control cells would tend to protect Friedreich's Ataxia cells against $\beta$-amino acid depletion. More work is presently under way in our laboratory in order to elucidate the mechanisms of regulation of $\beta$-amino acid transport in fibroblasts.

\section{ACKNOWLEDGMENTS}

These studies were supported by grants from the Medical Research Council of Canada, Le Ministère des Affaires Sociales du Québec (Réseau Provincial de Médecine Génétique) and l'Association Canadienne de l'Ataxie de Friedreich.

\section{REFERENCES}

BARBEAU, A. (1978) Friedreich's Ataxia 1978 - An Overview. Can. J. Neurol. Sci. 5: $161-165$.

BOOTH, C.W. and NADLER, H.L. (1975). Neutral amino acid transport in cultivated human skin fibroblasts. Proc. Soc. Exp. Biol. Med. 148, 277-282.

BUTTER WORTH,R. F., HAMEL, E., LANDREVILLE, F., and BARBEAU, A. (1978a). Cerebellar ataxia produced by 3-acetyl pyridine in rats. Can. J. Neurol. Sci., 5, 131-134.

FILLA, A., BUTTER WORTH, R., F., GEOFFROY, G., LEMIEUX, B. and BARBEAU, A. (1978). Platelet taurine uptake in spinocerebellar degeneration. Can. J. Neurol. Sci., 5, 119-123.

GROTH, V. and ROSENBERG, L. E. (1972). Transport of dibasic amino acids, cystine and tryptophan by cultured human fibroblasts: Absence of a defect in cystinuria and Hartnup disease. J. Clin. Invest., 51, 2130-2142. 
HILLMAN, R.E. and OTTO, E.F. (1974) Transport of $\mathrm{L}$-isoleucine by cultured human fibroblasts. J. Biol. Chem. 249. (II) $3430-3435$.

KAYE, C.I. and NADLER, H. L. (1976). Transport of L-cystine by cultivated skin fibroblast of normal subjects and patients with cystinosis. Pediat. Res. 10, 637-641.

LEMIEUX, B., BARBEAU,A., BERONIADE, V.,SHAPCOTT, D., BRETON, G., GEOFFROY,G. and MELANCON, S.B. (1976). Amino acid metabolism in Friedreich's Ataxia. Can. J. Neurol. Sci., 3, 373378.
MELANCON, S.B., GRENIER, B., DALLAIRE, L., POTIER, M., FONTAINE, G. GRIGNON, B., GEOFFROY, G., LEMIEUX, B. and BARBEAU, A. (1979). Dicarboxylic amino acid uptake in normal, Friedreich's Ataxia and dicarboxylic aminoaciduria fibroblasts. Can. J. Neurol. Sci., this issue.

PELLEFIGUE, F., DEBROHUN BUTLER, J. SPIELBERG, S. P., HOLLENBERG, $M$. D. GOODMAN, S. I. and SCHULMAN, J. D. Normal amino acid uptake by cultured human fibroblasts does not, require gamma- glutamyl transpeptidase. Biochem. Biophys. Res. Comm. 73, 4:997-1002.

REVSIN, B. and MORROW,G. (1976). Glycine transport in normal and non-ketotic hyperglycinemic human diploid fibroblasts. Exptl. Cell Res. 100, 95-103.

ULLRICH, J. and FROMTER, E. (1978). Active and passive transtubular transport in the proximal convolution. Proceed VII th Int. Congr. Nephrol. Montreal, Ed. R. Barcelo et al. pp. 147-154. 